\title{
Kilpailukyvyn mittaaminen elintarvikeketjussa
}

\author{
Csaba Jansik ${ }^{1} \&$ Xavier Irz ${ }^{2}$
}

Maailmantalouden nykyinen taantuma on nostanut kilpailukyvyn käsitteen keskustelujen fokukseen koko taloudessa. Joka maan ja joka sektorin tavoitteena on kilpailukyvyn nostaminen. Näin on myös elintarvikeketjun sisällä.

Euroopassa elintarvikealan kilpailukyky ja sen mittaaminen keskittyi monesti yksittäiseen toimialaan tai muutaman maan vertailuun ja tutkimuksia harvoin päästiin hyödyntämään konkreettisten toimialojen yritysten kesken. Yksi näitä tutkimuksen ja elinkeinon välisiä harvoja ja ainutlaatuisia yhteistyömuotoja edustaa IFAMA (International Food and Agrobusiness Management Association), joka itse on ollut toiminnassa vain vähän yli kaksikymmentä vuotta. 2000-luvulla valmistuneet laajat tutkimukset (esim. LEI) herättivät huolta Euroopan elintarvikealan alhaisesta kilpailukyvystä maailman muihin alueisiin nähden. Elintarviketeollisuuden toimialayhdistykset ryhtyivät kilpailukykynsä säännöllisempään syyniin, kuten viime vuosien CIAA:n (Confederation of the Food and Drink Industries of Europe) vuosittaiset kilpailukykyraportit osoittavat.

Kilpailukyky-käsitteen merkitystä on viime vuosina ymmärretty yhä enemmän myös Suomen elintarvikeketjussa. Kilpailukykyinen elintarvikeala menestyy paitsi kotikentällään niin myös vientimarkkinoilla. Mutta mitä kilpailukyky on ja mistä se koostuu?

Kilpailukyky on moniulotteinen ja vaikea käsite ja yhtä vaikea on sen mittaaminen. MTT Taloustutkimuksessa on koottu kirjallisuuden pohjalta 15 tunnuslukua käsittävä mittaristo, jota testataan Suomen ja naapurimaiden liha- ja maitoketjujen vertailuun. Mittaristolla pyritään valottamaan kilpailukyvyn viisi ulottuvuutta: tuottavuutta, ulkomaankaupan ja taloudellisen toiminnan suorituskykyä, kasvua ja innovaatiota. Mittariston toimivuutta, käytännön esimerkkejä sekä aineistoa ja sen mahdollisten puutteiden tuomia haasteita esitetään Itämeren maiden liha- ja maitosektoreiden lukuja käyttäen.

Asiasanat: kilpailukyky, tuottavuus, elintarvikeketju, elintarviketeollisuus

\footnotetext{
${ }^{1}$ MTT Taloustutkimus, Latokartanonkaari 9,00790 Helsinki, csaba.jansik@mtt.fi

${ }^{2}$ MTT Taloustutkimus, Latokartanonkaari 9,00790 Helsinki, xavier.irz@mtt.fi
} 


\section{Measuring Competitiveness in the Food Supply Chain}

\section{Introduction}

The food and drink industry plays a significant role in the economy of the European Union. Its total sales revenues amounted to $€$ billion 954 in 2009 , or $12,9 \%$ of the manufacturing sector, ranking it to the first place among the manufacturing sub-sectors.

Due to the strategic importance of food and the significance of food industry within the European manufacturing sector, measuring and monitoring food industry competitiveness is essential. Yet, it has not been done rigorously until the very recent years, when eventually numerous efforts have been made to identify the competitive position of European food manufacturing. The broad investigation financed by the European Commission (Poppe et. al, 2006) came to the conclusion that the competitiveness of the European food sector on the world markets is poor compared to other regions such as Latin America, U.S.A. or Oceania. The finding was confirmed in the recently published annual competitiveness reports of the Confederation of the Food and Drink Industries of the EU (CIAA, 2008b), although some improvements were shown in certain sub-areas.

Competitiveness of an industry, such as the food sector, is achieved when individual companies within that industry are able to sell goods or services at a price and quality that compare favourably to those of competitors. Competitiveness therefore relates closely to concept of productivity, defined as the efficiency of the process by which firms (or sectors) transform inputs into outputs. Indeed, for entire countries or large sectors of an economy, some prominent economists consider that competitiveness is just "a funny way of saying "productivity" (Aiginger, 2006, summarizing Krugman, 1994). In a similar vein, the UK Department for Environment, Food and Rural Affairs concluded its review of competitiveness indicators for the food chain industries by stating that "at root, competitiveness should be viewed as being about economic efficiency or productivity" (DEFRA, 2002). This suggests that competitiveness can be measured according to three different types of indicators:

- Indicators that directly measure productivity and economic efficiency.

- Indicators that measure the consequences of efficiency, such as trade performance.

- Indicators that measure the factors that will contribute to future productivity, such as R\&D investments.

The competitiveness of the Finnish food sector is of crucial importance. Improving competitiveness is the key to survival not only on export market, but even more importantly on the domestic market.

\section{Research projects to measure Finnish competitiveness}

Measuring competitiveness is, therefore, of utmost importance to the Finnish food supply chain. Several projects have been designed to conduct this specifically to particular chains such as the meat, dairy, grain, oilseed and sugar chains. Two of these projects are currently in the phase of accomplishment, while others are in the planning stage.

The primary objective is to measure the competitiveness of the Finnish food chain and compare it to that of its neighbouring countries in Northern Europe. Competitiveness is a multi-dimensional concept and this investigation will therefore rely on a range of indicators, which will be analysed across countries and over time.

The second objective of these projects is to determine the factors that affect competitiveness of food sectors in the Northern European countries, including factors such as R\&D investment, market structure, or direct foreign investment.

The final objective is to draw conclusions and formulate recommendations from the analysis to inform the strategic decisions of all the stakeholders of the Finnish food sector, including farmers, food processors, retailers, as well as policy makers.

The set of competitiveness indicators collected, calculated and analysed for the dairy and meat chains within the on-going projects will provide a general scheme and basis for comparable competitiveness analyses of the sugar, grain, and oilseed supply chains in the future. 


\section{Methodology}

Competitiveness of the Finnish food sector is measured and compared to seven other countries around the Baltic Sea, namely Estonia, Latvia, Lithuania, Poland, Germany, Denmark and Sweden in two ongoing projects concerning the dairy and the meat sectors. The following five topics are investigated and measured by indicators:

(1) Productivity

(2) Trade performance

(3) Economic performance, market and ownership structure

(4) Growth

(5) Innovation

Whenever data are available at a reasonable price, efforts are made to collect and calculate comparable indicators for all or at least part of the countries specified in the above geographical coverage.

\section{(1) Productivity}

Productivity is one of the most familiar and intuitive performance indicators of a firm, and is a key driver of economic growth and firm profitability. The productivity of a firm or sector is simply defined as the ratio of outputs (e.g., yoghurt, butter) to inputs (e.g., labour, milk) (Coelli et al., 1998, p. 2). If the production process involved a single input and a single output, calculating productivity would be straightforward, but this is unfortunately never the case in reality, where firms combine multiple production factors in order to manufacture a whole range of products. Hence, the problem of measuring productivity becomes one of aggregating inputs and outputs into appropriate indices. This can be achieved by application of various methods that differ in terms of accuracy, ease of implementation and data requirements, but two types of measures can be usefully distinguished:

- Partial productivity measures, which simplify the problem of aggregating inputs by focusing on a single production factor, such as labour or capital. The main advantage is the ease of calculation and interpretation, but it comes at the cost of accuracy. For instance, a high level of labour productivity can reflect high efficiency resulting from the use of superior technology, but it could also be due to the inefficient substitution of capital for labour.

- Total Factor Productivity (TFP) measures integrate all inputs and all outputs in the calculation. For instance, the traditional indices, such as Laspeyres, Paasche, Fisher, and Törnqvist use price information to aggregate total outputs and inputs. When there is no price information, distance function productivity measures (e.g., Luenberger productivity indicators, Malmquist and Hicks-Moorsteen productivity indexes) can be an alternative. These measures are directly based on technology and input-output quantities.

Against this background, we propose to establish an international comparison of productivity levels in the food sector. The Finnish food sector will be benchmarked against the food sectors of neighbouring countries. Because of data limitations, it is likely that this comparison will only be possible on the basis of partial productivity measures. Labour productivity time series will be calculated for milk farming of all eight countries using FADN data. Labour productivity will also be calculated for food industries of the region depending on data availability.

We will also build an index of Total Factor Productivity using Statistics Finland's Industrial Statistic data base on the manufacturing sector (http://pxweb2.stat.fi/database/ StatFin/teo/atoi/ atoi_en.asp) and Producer Price Indices (http://pxweb2.stat.fi/database/StatFin/hin/thi/thi_en.asp). This task will involve two main difficulties related to the construction of a capital stock variable and appropriate price indices for each input and output. The results will be analysed by comparing them to rates of TFP growth available from the literature for other sectors and countries.

Applied indicators:

- Labour productivity

- Total factor productivity (TFP)

- Other natural productivity indicators 


\section{(2) Trade performance}

Trade performance is a result of competitiveness, therefore foreign trade indicators also indicate differences in competitiveness. Although trade performance also involves factors such as historic and current foreign trade relations, geographical location, distances and freight costs etc., there is a general tendency for competitive countries and industries to succeed on export markets compared to less competitive ones.

The revealed comparative advantage (RCA) index is a commonly used indicator to assess trade performance. Balassa (1965) derived the index that measures a country's comparative advantage in the trade of a branch of the economy, an industry or even a specific product group or a given product by its share in the country's total exports relative to the particular industry's or product's share in the total world export. The formula of the index is:

$$
\text { RCAij }=100(X i j / X w j) /(X i t / X w t),
$$

where $\mathrm{Xij}$ is the export of country $\mathrm{i}$ in the case of product $\mathrm{j}$; $w$ denotes world export and $t$ the export of all products or total export. If the index takes a value in excess of unity, the country has comparative advantage in the given product group, in other words the country is specialised in producing and exporting this product. As Havrila and Gunawardana (2003) pointed out, the indices have been widely applied in empirical studies, but there are various ways to interpret them. RCA indices will be calculated by using Eurostat and FAO databases.

Another indicator will be export share in sales revenues of a particular food industry, which is tightly related to the growth indicators. Since demand on the domestic market in most of the countries stagnates or grows very slow, it is easier to achieve growth on the export markets.

Export performance can be scrutinised in detail on two highlighted market area, which both are the most relevant markets for the Northern European food industries: EU-27 and Russia. Particularly in the Russian market some of the new EU member states have succeeded to increase their agrifood exports manifold since the end of the 1990s.

Applied indicators:

- Balassa indices (RCA)

- Export share in sales revenues

- Market share as proportion in agrifood imports in highlighted markets e.g. EU-27, Russia

\section{(3) Economic performance, market and ownership structure}

Competitiveness and economic performance are interrelated on the firm level: competitive firms tend to earn higher profit than less competitive ones. On the industry level and among countries the correlation is not automatic, because of different ownership and strategy of the individual companies and varying taxation among the countries. Company strategy may change according to the majority ownership being in the hands of farmers, shareholders, or foreign owners. Profitability ratio is still an indicator that can be used for international comparison.

Market structure will be analysed by concentration indicators in the food industry and farm structure changes in agricultural production. Concentration ratios (CR4) can be used to compare concentration in the industry, while in the agricultural farm structure changes will be illustrated by Lorenz curves.

Applied indicators:

- Profitability ratio (net profit to sales revenues)

- Concentration in the food industry (CR4)

- Crop and livestock farm structure, average farm size

- Prices of various foodstuffs

- Share of foreign vs. domestic ownership in company capital 


\section{(4) Growth}

In a dynamic world, an increase in competitiveness of the food sector implies, by definition, an enhanced ability to sell food products domestically or internationally. Hence, changes in competitiveness and output growth are intricately linked, and we therefore propose to analyse the growth of the food sub-sectors in Finland and other countries by reporting the evolution of three growth indicators over time.

The growth of food industry sales revenues is a performance measure of the entire food sector. The growth of food production value better captures the changing competitiveness of primary producers. Finally, the growth of agrifood exports gives information more specifically about the change in the competitive position of the sector internationally.

Applied indicators:

- Growth of food industry sales revenues

- Growth of food production value

- Growth of agrifood exports

\section{(5) Innovation}

Productivity is fundamentally a dynamic process driven by innovation as well as the generation and exploitation of knowledge. Hence, current productivity levels reflect to a large extent investment decisions that were made in the past. Looking forward, it is therefore important to assess whether the food sector in Finland is taking the necessary steps to ensure that it will maintain or improve its position relative to competitors in the short to medium term. Given that productivity growth is primarily driven by technological change, this means that particular attention should be paid to investments in Research and Development $(R \& D)$ as well as the rate of innovation in the sector.

\section{Applied indicators}

- R\&D expenses/value added

- $R \& D$ expenses/sales revenues

\section{Preliminary results of the meat and dairy sectors}

The economic performance of the Finnish meat supply chain as measured by the growth rate of Total Factor Productivity (TFP) has been strong during the period of EU membership (1995-2007). TFP grew at the estimated average annual rate of $2.6 \%$ in the meat processing sector, $3.9 \%$ on pig farms, and $3.9 \%$ on specialised beef farms. Those rates compare favourably to those estimated for the whole of the Finnish food industry, the entire agricultural sector, or the whole of the manufacturing industry. They can also be considered high by international standards. Hence, the extensive restructuring and large investments that have taken place throughout the meat supply chain have contributed favourably to its overall economic performance.

Dairy farms have experienced fast structural change from 1995 to 2008, with rapid substitution of capital and intermediate inputs (e.g., feeds) for labour. This process has yielded dividends in terms of TFP, which has grown relatively rapidly at the average annual rate of $2.5 \%$. However, there are also signs that the pace of productivity growth on dairy farms is slowing down. Further down the chain, the dairy processing sector has reduced its labour force significantly and, following a period of stagnation stretching to 2003, TFP has started growing again, suggesting that the investments in tangible assets made in the sector are finally paying off. 


\section{References}

Aiginger, K. (2006): Revisiting an evasive concept: introduction to the special issue on competitive-ness. Journal of Industrial Competition \& Trade, 6: 63-66.

Balassa, B. (1965): Trade Liberalization and Revealed Comparative Advantage, The Manchester School of Economic and Social Studies 33, pp. 99-123.

CIAA, Confederation of the food and drink industries of the EU (2010): Data and Trends of the European Food and Drink Industry 2010, Brussels.

CIAA, Confederation of the food and drink industries of the EU (2008): CIAA Review of key com-petitiveness, indicators, Brussels.

Coelli, T., Rao, D. S. P. \& Battese, G. E. (1998): An introduction to efficiency and productivity analysis, Kluwer Academic Publishing, Boston.

DEFRA (2002). Development of competitiveness indicators for the food chain industries, DEFRA Working Paper, Economics (international) Division.

Ebneth, O. and Theuvsen, L. (2005): Internationalization and Financial Performance of Cooperatives Empirical Evidence from the European Dairy Sector, presented at the IAMA World Forum and Symposium in Chicago, June 2005 (available at IAMA conference website (link referred at October 9, 2009):

http://ifama.org/tamu/iama/conferences/2005Conference/Papers\&Discussions/1014_Paper_Final.pdf

Hadley, D. \& Irz, X. (2008): Productivity and farm profit - a microeconomic analysis of the cereal sector in England and Wales, Applied Economics, 40: 613-624.

Havrila, I. \& Gunawardana, P. (2003): Analysing Comparative Advantage and Competitiveness: An Application to Australia's Textile and Clothing Industries. Australian Economic Papers, Vol-ume 42, Issue 1, pp. 103-117.

Irz, X. \& Thirtle, C. (2004): Dual technological development in Botswana agriculture: A stochastic input distance function approach, Journal of Agricultural Economics, 55(3): 455-478.

Jansik, C. (2009): A Comparison of Dairy Supply Chains in Finland and in the Baltic Countries, presented at the IAMA World Forum and Symposium in Budapest, June 2009 (available at IAMA conference website: http://www.ifama.org/library.asp?collection=2009_budapest\&volume=symposium/1077_paper.pdf link referred at October 9, 2009)

Niemi, J. \& Ahlstedt, J. (eds) (2009): Finnish Agricultural and Rural Industries 2009, MTT Economic Research, Publications no 109a, Helsinki.

Krugman, P. (1994). Competitiveness: A dangerous obsession, Foreign Affairs, 73(2): 28-44.

Poppe K., Wijnands J. \& van der Meulen (2006): Competitiveness of the European Food Industry - An economic and legal assessment. European Comission, Brussels and LEI, The Hague.

Tiffin, R. \& Irz, X. (2006). Is agriculture the engine of growth? Agricultural Economics, 35: 79-89. 